\title{
A hibrid hajóhajtás alkalmazási lehetósége a folyami közforgalmú közlekedésben
}

A vízparton fekvö európai nagyvárosokban az 1970-80-as években megkezdödött a természetes vizek „visszahelyezése” egyrészt a polgári élet, másrészt a városépítészet és a mobilitás helyszínévé, központjává. Budapest és agglomerációja ebben a tekintetben kiemelt jelentóséggel bír, nemcsak rendkívüli szépségü környezete, valamint az agglomerációba kitelepültek ingázása, hanem a közlekedés helyzete miatt is. A fővároson belïl - az évszázados városszerkezetnek köszönhető közúti infrastruktúra kedvezőtlen helyzete miatt - hatalmas forgalom alakult ki a rakpartokon és a bevezetó utakon egyaránt. Ezt a problémát a bevezetni tervezett „dugódíj” önmagában nem lesz képes megoldani. Ésszerüen azonban egy új, alternatív közlekedési mód, a környezetbarát hajózás jelentheti a megoldást.

DOI 10.24228/KTSZ.2017.4.3

\section{Dr. Simongáti Győző - Hargitai L. Csaba - Réder Tamás}

Budapesti Múszaki és Gazdaságtudományi Egyetem, Vasúti Jármúvek, Repülőgépek és Hajók Tanszék

E-mail: gysimongati@vrht.bme.hu, cshargitai@vrht.bme.hu

\section{BEVEZETÉS}

Egy átlagos tengeri áruszállító hajónál a hajó üzeme egyenletes, ami azt jelenti, hogy a hajó az üzemidő túlnyomó többségében a tervezési sebességhez tartozó névleges, tehát a hajóba beépített motor maximális teljesítményéhez közeli értéken üzemel, jó teljesítménykihasználással és hatásfokkal. Ez az olyan hajókra, mint a budapesti közforgalmú közlekedést is szolgáló hajók, nem mondható el. Itt a hajó üzeme egyenetlen, a beépített fögép teljesítménye tág határok között ingadozik, a névleges teljesítményt ritkán használják $\mathrm{ki}$. Az üzemidő nagy részében a motor részterhelésen megy, ami nagyobb fajlagos üzemanyag-fogyasztást és károsanyag-kibocsátást jelent. Ez a probléma a szárazföldi és légi közlekedésben is megfigyelhető. Míg a repülőgé- peknél a hajtóművek optimalizálásával [1], a közúti és vasúti jármüveknél a hibridhajtásrendszer fejlesztésével [2] próbálják kezelni az ingadozó teljesítménykihasználást. A tengeri hajózásban is vannak a közösségi közlekedést kiszolgáló hajókhoz hasonló, változó üzemi profillal rendelkező tengeri hajók (mint pl. az olajkitermelő platformokat ellátó, horgonykezelö hajók), amelyeknél ma már dominánsnak nevezhető a dízel-elektromos vagy éppen hibridhajtás-rendszer alkalmazása a gazdaságosabb üzemeltetés érdekében [3]. Ez a jelenség adta a motivációt annak vizsgálatához, hogy a dunai közlekedésben használt hajótípusoknál várható-e gazdaságossági javulás a jelenlegihez képest az első megközelítésre célszerübbnek tünő hibrid hajtás esetén. E cikk azonban csak a témában folyó kutatás első lépéseiről és lehetőségeiről számol be. 


\section{A HAJÓ BEMUTATÁSA}

Jelenleg a BKV a közforgalmú közlekedésben többféle hajótípust üzemeltet vagy saját maga, vagy alvállalkozói révén. Legismertebb típusaik a 100 fö befogadására alkalmas, ún. 100-asok (BKV 100) és a 150 fös vízibuszok, az előzőekből $5 \mathrm{db}$, utóbbiakból $2 \mathrm{db}$ van üzemben [4]. Sajnálatos módon - bár a hajók magyar tervezésüek - a hajókról nagyon kevés eredeti műszaki terv lelhető fel, és ezen az átalakítások során készített tervek sem segítenek sokat. A legtöbb információ a BKV 100-as típusról állt rendelkezésre. Mindezek alapján úgy döntöttünk, hogy nem egy tényleges, hanem egy fiktív hajón végzünk elemzést, amelyhez alapadatokat a BKV 100 típusa szolgáltat. Ahol nincs elérhető információ, ott becsléssel, közelítéssel, egyéb minták alapján igyekeztünk pótolni a hiányt.

\subsection{A BKV 100 személyes hajótípusa}

A típus hajói $1 \mathrm{db}$ hajtásra használt dízelmotorral rendelkeznek, ami redukciós hajtómüvön keresztül hajtja a $4 \mathrm{db}$ fix szárnnyal rendelkező hajócsavart. A hajó elektromos energiaellátását akkumulátor-telep biztosítja, mely inverteren keresztül látja el a $230 \mathrm{~V}$-os fogyasztókat. Az akkumulátorok töltését a fömotor generátora végzi. Külön segédüzemi generátor nincs a hajón. A hajót az 1. ábra illusztrálja, főbb adatait a [5] és saját információk alapján az 1. táblázat tartalmazza.
A fiktív vizsgálat tárgyát képező hajó főméreteit és hajtását tekintve az itt megadottakkal azonos paraméterekkel rendelkezik. Az ennél mélyebb információk már becsült vagy önkényesen felvett, nem biztos, hogy a valóságnak megfelelő adatok lennének.

\subsection{A hajó üzemeltetési profilja}

A hajó üzemeltetési profilja megmutatja, hogy a hajtómotor(ok) különböző teljesítményszintjei az üzemidő hány százalékában jelentkeznek. Ebből megállapítható, hogy a motor(ok) névleges teljesítményét milyen mértékben használják ki az üzemidő alatt. Amennyiben az üzemeltetési profil egyenetlen, úgy érdemes elgondolkodni

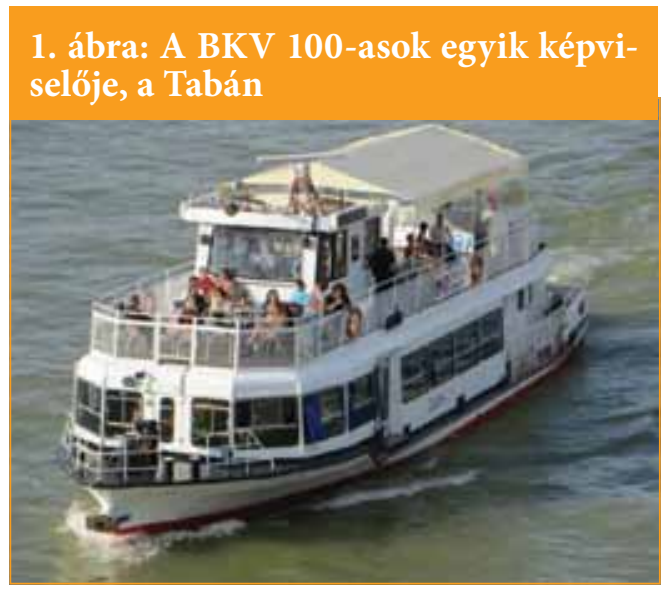

\section{1. táblázat: A BKV 100 föbb adatai}

\begin{tabular}{|l|l|}
\hline Besorolás: & BKV 100 típusú átkelőhajó \\
\hline Épült: & $1982-86$, MHD Balatonfüredi Gyáregysége \\
\hline Legnagyobb hossz: & $24,4 \mathrm{~m}$ \\
\hline Függélyek távolsága: & $23,25 \mathrm{~m}$ \\
\hline Legnagyobb szélesség: & $6,42 \mathrm{~m}$ \\
\hline Szélesség a föbordán: & $6,0 \mathrm{~m}$ \\
\hline Oldalmagasság: & $1,6 \mathrm{~m}$ \\
\hline Szabad oldal: & $0,65 \mathrm{~m}$ \\
\hline Fixpont magasság: & $6,14 \mathrm{~m}$ \\
\hline Legnagyobb merülés: & $1,1 \mathrm{~m}$ \\
\hline Vízkiszorítás: & $64,5 \mathrm{t}$ \\
\hline Sebessége holt vízben: & $18 \mathrm{~km} / \mathrm{h}$ \\
\hline Befogadó képessége: & $\begin{array}{l}100 \mathrm{személyes} \mathrm{termes} \mathrm{hajó,} \mathrm{amely} \mathrm{az} \mathrm{alsó} \mathrm{fedett} \mathrm{részen} \mathrm{biztosítja} \mathrm{az} \mathrm{ülöhelyeket,} \mathrm{a} \mathrm{felső} \\
\text { nyitott fedélzeten 20 fö tartózkodhat. }\end{array}$ \\
\hline $\begin{array}{l}\text { Fögép teljesítménye/for- } \\
\text { dulatszáma, típus: }\end{array}$ & $\begin{array}{l}265 \mathrm{~kW} 2000 \text { 1/perc, Doosan L126 TIH, soros, } 4 \text { ütemü, vízhütéses, közvetlen befecs- } \\
\text { kendezéses, gyorsfordulatú motor }\end{array}$ \\
\hline
\end{tabular}


annak okairól, és amennyiben indokolt, meg kell vizsgálni egyéb hajtásrendszerek alkalmazhatóságát, gazdaságosságát.

$\mathrm{Az}$ üzemeltetési profil felvételét általában a fömotor(ok) tengelyén mérhető nyomaték és a tengely fordulatszámának mérésével lehet végrehajtani, mely adatokat az aktuális idő függvényében lehet ábrázolni. A nyomaték és a fordulatszám értékekből számítható a motor által leadott teljesítmény. A teljesítményre sávokat meghatározva egy könnyen áttekinthető diagramot kapunk. A mérést kiegészítve a hajó aktuális pozíciójának, sebességének, fordulási jellemzőinek, a motor(ok) üzemanyag-fogyasztásának, a hajó merülésének (rakomány tömegének) és a külső körülmények jellemzőinek (szélirány, sebesség, folyó áramlási sebesség) felvételével, olyan komplex információhalmazt kaphatunk, amelyből a hajó üzemeltetője hasznos következtetéseket vonhat le a gazdaságos üzemeltetéssel kapcsolatban.

A BKV 100-as hajókhoz nem állnak rendelkezésre ilyen mérésen alapuló eredmények, amit a fiktív hajóhoz használni lehetne. Ugyanakkor elérhető az Internet segítségével számos olyan adat, amelyekkel az üzemeltetési profil - a fiktív hajó számára mindenképpen elfogadható - közelítéssel meghatározható. Ennek módszere:

A fiktív hajó ismert geometriai és úszáshelyzeti adatai alapján meghatároztuk a hajó ellenállását az egyes haladási sebességeknél. Az ellenállás számításnál érdes, festett acélfelületet vettünk figyelembe a súrlódási ellenálláshoz. Sekélyvíz hatással egyelőre nem számoltunk, mert a hajók nagyon változatos pályát futnak be, és annak meghatározása, hogy hol érvényesül a sekélyvízi ellenállást növelö hatása és hol nem, további, jelenleg rendelkezésre nem álló adatokat igényelt volna. Az ellenállásból az effektív teljesítmény számítható, amiből egy becsült propulziós hatásfok segítségével a közelítő hajtási teljesítmény is kalkulálható. Eredményként megszületik a hajó sebesség-teljesítmény (P-v) diagramja. Ezek után a hajó egy teljes menetciklusát (sebesség-idő, azaz v-t diagram) vettük fel, amely egy völgymeneti és egy hegymeneti szakaszból áll, a megfelelő közbenső kikötők érintésével, az utasok be- és kiszállításával együtt. A menetciklus tartalmazza, hogy az adott időpontban a hajó milyen sebességgel közlekedik. Ebben a közelítő módszerben a marinetraffic.com hajókövető weboldal Tabán-ról szolgáltatott adatait használtuk fel a menetciklus felvételéhez (a publikus hajókövető alkalmazás ezen túl a hajó pozícióját is megadta). A nyert adatokból az egyes megállók közti haladási sebességeket és a haladás idejét táblázatba foglaltuk. A megállóban tartózkodás idejét, amikor a motor üresjárati fordulaton üzemel, 2 percnek feltételeztük. A folyó sodrása miatt ahhoz, hogy adott haladási sebességekhez pontos teljesítményértékek szülessenek, a marinetraffic.com hajókövető weboldal által közölt talajhoz viszonyított sebességeket korrigálni kellett a sodrási sebességgel. Völgymenetben az adott sebességből kivontuk, míg hegymenetben hozzáadtuk a folyó sodrási sebességét (amit átlagosan $1,25 \mathrm{~m} / \mathrm{s}-\mathrm{ra}$ vettünk fel). Az így kapott egyes korrigált sebességekhez a már előzőekben említett P-v diagram alapján leadott teljesítményértékeket rendeltünk. A teljes teljesítménytartományt 30 egyenlö részre osztottuk, majd az ezen tartományokba eső teljesítmények leadásának idejét összegeztük. A teljes idő segítségével így számítható lett, hogy az adott teljesítményen az üzemidő hány százalékában jár a motor. A névleges teljesítménysávokhoz tartozó időtartamokat a hegy- vagy völgymenet menetidejének százalékában ábrázolva megkaptuk a hegy- vagy völgymenetre vonatkozó üzemeltetési profilt.

Az üzemi profilt a Tabán hajó Árpád út - Haller utca - Árpád út viszonylatához készítettük el (egy völgymenet és egy hegymeneti szakasz). Az így kapott eredményeket a 2. és 3. ábra mutatja. A 4. ábrán a hegy- és völgymeneti szakaszra vonatkozó üzemi profilok összesítése, vagyis a teljes menetciklusra vonatkozó diagram látható. A fenti módszer szerint elkészített üzemi profil Dax Szabolcs, Juhász Bertalan, Krizsik Donát és Réder Tamás hajómérnök BSc-s hallgatók előkészítő munkáján alapult.

2. ábra: Hegymenet ïzemi profil

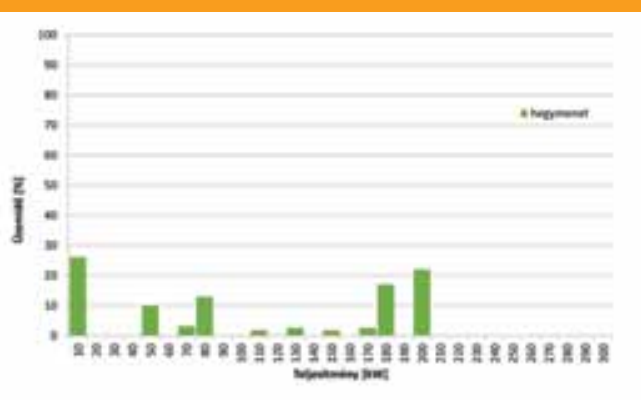




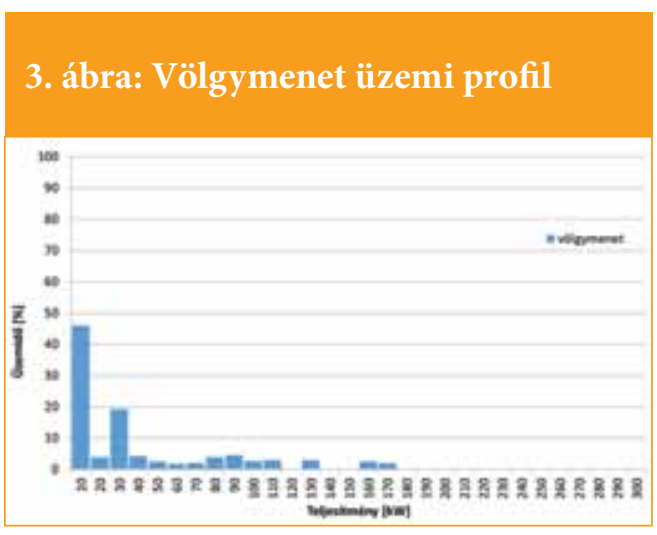

Az előző két ábrából kitűnik, hogy völgymenetben a folyó sodrása miatt a hajónak a menetrend biztosításához messze elegendő sebessége van, a hajtógépet alig kell terhelni, azt is csak inkább a kikötési manőverek során és a hosszabb állomások közötti távolságok esetén (ahol nagyobb sebességre gyorsítható a hajó). Látható továbbá, hogy hegymenetben is az üzemidő nagy százalékában maximum $2 / 3$ teljesítményen üzemel a motor, ami a kis állomások közötti távolságnak is köszönhető. Az egyesített diagramból (4. ábra) megállapítható, hogy az üzemidő legnagyobb részében a hajó csak kifejezetten kis teljesítményt igényel, tehát a beépített $265 \mathrm{~kW}$-os teljesítményü főgép alacsony kihasználtság mellett, gyakorlatilag mindig részterhelésen üzemel.
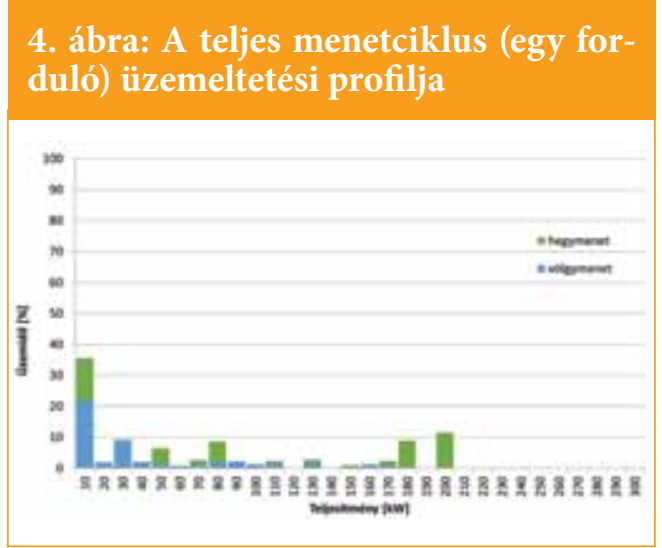

Mindezek a közelítő eredmények arra mutatnak, hogy mindenképpen érdemes megvizsgálni egy ehhez az üzemi profilhoz jobban igazodó hajtásrendszer beépíthetőségének lehetőségét és alkalmazásának gazdaságosságát.
Az itt közölt közelítő számításból származó eredmények jellegre és minőségileg nagyon jól közelítik a valóságot, így kvalitatív értékelésre mindenképpen alkalmasak. Célunk elsősorban annak bemutatása, hogy milyen módszerrel lehet elemezni, számszerüsíteni egy hibrid hajtás létjogosultságát. Ehhez a fenti közelítő eredmények kiválóak. A tényleges hajóra vonatkozó vizsgálattal kapcsolatban azonban szükségesnek tartjuk megjegyezni, hogy az üzemi profilt mindenképpen célszerü méréssel verifikálni.

\subsection{A segédüzem energiaigénye}

A hajó - amint elszakad a parttól - egy teljesen autonóm rendszer, amelyben minden szükséges energiát a fedélzeten kell megtermelni. A hajó üzeméhez szükséges egyéb (tehát a hajtáson kívüli) eszközök, berendezések energiaellátását a segédüzemi rendszer végzi. Mivel a fogyasztók jellemzően elektromos energiát igényelnek, így ez a rendszer általános esetben egy dízelmotor-generátor egységéből és a hozzátartozó elektromos elosztórendszerből áll.

A mintául szolgáló hajótípuson ilyen klasszikus segédüzemi rendszer nincs, és sajnálatos módon egyelőre a segédüzem energiaigényéről sincs elegendő információ. Jelenleg a segédüzemben müködő elektromos fogyasztókat akkumulátorokról szolgálják ki, amelyeket a fömotor generátora tölt. A gyakorlat mutatja, hogy a beépített akkumulátorokkal csak a mindenképpen szükséges fogyasztók igénye elégíthető ki, és az olyan kényelmi berendezések, mint egy megfelelő teljesítményű klímaberendezés, ilyen módon már nem látható el energiával.

Fentiek miatt a hibrid hajtás elemzésénél a segédüzem energiaigényével nem számolunk (sem a hagyományos sem a hibrid változatra), így az összehasonlítás nem lesz torz. Megjegyezzük azonban, hogy általában véve minél nagyobb egy hajón a segédüzemi villamosenergia-igény, annál inkább valószínű, hogy egy hibrid vagy dízel-elektromos hajtásrendszer összességében kedvezőbb energiafogyasztást eredményez. 


\section{A HIBRID HAJTÁS ALKALMAZÁ- SÁNAK LEHETŐSÉGEI HAJÓKNÁL}

Ahogy a szabad pályán mozgó szárazföldi járművekre, így a hajókra is jellemző, hogy a szükséges mozgási energiát a hajón lévő energiaforrásból, a propulziós hajtásrendszerrel állítják elő. $\mathrm{Az}$ energiát jellemzően kémiai energia formájában tárolják a fedélzeten (pl. fosszilis tüzelőanyagok, akkumulátor), de rendelkezésre állhat az a mechanikai (pl. vitorlás hajó, lendkerekes hajó, köteles komp), hö- (pl. gőztartályos motorcsónak) vagy belső energia (pl. pneumatikus vagy hidraulikus hajtás) formájában is.

Amikor a hajó mozgási energiáját több, különböző fajtájú energiaforrás is biztosíthatja, a propulziós hajtásrendszert hibrid hajtásnak nevezzük. A hibrid hajtásokat alapvetően a hibrid hajtásrendszer célja és az energialánc felépítése szerint lehet csoportosítani:

\subsection{Csoportosítás a hibrid hajtásrend- szer célja szerint}

A hibrid hajtásrendszer célja szerinti összehasonlítás az egyes megoldásokkal megvalósítandó elsődleges feladat szerinti értékelést jelenti, de emellett a másodlagos jellemzők is rendkívül nagy befolyással vannak a megfelelö rendszer kiválasztásában. A jelenleg ismert hibrid hajtásoknál alapvetően négy fö feladat különböztethető meg:

\subsubsection{Energiahatékonyság}

A hibrid hajtáslánc kialakításának alapvető célja, hogy a hagyományos (vagy más) hajtásrendszerekhez képest jobb hatásfokkal használják fel az energiát a hajó (nem csak a meghajtás, hanem az egyéb fedélzeti fogyasztók) energiaigényének fedezésére. A hibrid hajtáslánc elemeinek meghatározása során, úgy választják meg az összetevőket, hogy a hajó különböző üzemállapotaiban az egyes gépegységek az optimális (legjobb hatásfokú) munkapont körüli üzemben müködjenek. A szárazföldi jármüveknél az energiahatékonyságot növelheti a féküzem közbeni energiavisszatáplálás, azonban a hajóknál ez üzembiztosan és gazdaságosan még nem kivitelezhetö.
Jellemzően a változó teljesítménykihasználású hajóüzemnél lehet a hibrid hajtással energiahatékonyságot növelni (ezzel együtt üzemanyag-fogyasztást csökkenteni), amire jó példák a szállodahajók, a tengeri ellátó hajók.

\subsubsection{Fajlagos tömegcsökkentés}

Elsősorban a nagysebességű hajóknál, illetve a katonai vízi járműveknél megjelenő elsődleges tervezési szempont. Ekkor az energiaátalakítás hatékonysága helyett a hajtásrendszer teljesítmény - tömeg aránya fontos, mivel a nagy sebesség elérése, vagy a hasznos hordképesség növelése érdekében a hajó önsúlyát csökkenteni kell. Például egyes tengeri kompoknál a nagysebességủ haladás teljesítményigényét gázturbinával, a normál sebességü haladásnál pedig kisebb teljesítményű dízelmotorral biztosítják, amelyek öszszehajtó hajtóművön keresztül ugyanazt a hajócsavart forgatják a különféle üzemállapotokban.

\subsubsection{Környezetterhelés}

Jóllehet a hajózás a legkisebb környezeti terheléssel járó szállítási mód, a hajók károsanyagkibocsátása egyre jelentősebb tervezési szempont. Gyakran összekeverik e szempontot az energiahatékonysággal, ugyanis ha egy hibrid meghajtási rendszer jobb hatásfokkal hasznosítja az energiaforrásokat, csökken az üzemanyag-fogyasztás, s vele együtt a hajó lokális emissziója.

Azonban elöfordulhatnak olyan tervezési határparaméterek, amelyek egy kis emissziójú, de rosszabb energiahatékonyságú, valamint egy nagyobb emissziójú, de jobb energiahatékonyságú hajtás együttes jelenlétét teszik szükségessé egy hajón. Ekkor a teljes hajóüzemben felhasznált energia több, mint ha csak a jobb energiahatékonyságú rendszer üzemelne. Ilyen tervezési feltétel lehet például, hogy a hajó tervezett útvonala károsanyag-kibocsátás korlátozású vízterületeken vezet keresztült, vagy a hajótulajdonos bizonyos üzemmódokban (pl. kikötői manőverezés) emisszió nélküli hajót szeretne üzemeltetni.

Megjegyezzük, hogy a környezetterhelés és az energiahatékonyság kérdését nem csak az adott hajó által elfogyasztott üzemanyag és az üzemeltetés során kibocsátott káros anyag te- 
kintetében lehet vizsgálni, hanem a hajó teljes életciklusában felhasznált energiaforrások és emisszió szempontjából is („well to wheel”). A lokális és a teljes életciklusú megközelítés sok esetben ellentétes eredményt ad. Például egy „tiszta”, elektromos meghajtású hajó lokális károsanyag-kibocsátása nulla, azonban az akkumulátorok gyártástechnológiája és a töltéshez használt villamos hálózat előállítása miatt a teljes üzemanyag-fogyasztás és a teljes emisszió nagyobb, mintha egy dízelmotor biztosítaná a meghajtást.

\subsubsection{Gazdaságosság és eladhatóság}

A hibrid hajtásrendszer konstrukciók általában költségesebbek, mint a hagyományos meghajtások, mivel több, bonyolultabb és sokszor egyedi gyártású rendszerelemet tartalmaznak. Azonban a nagy teljesítményigényü, változó teljesítménykihasználású hajóknál az egyedi gyártású nagy teljesítményü motor beépítése helyett, a több kisebb teljesítményü meghajtó egységből (akár hibrid rendszerben) felépített meghajtás akár olcsóbb is lehet. Ezen kívül az energiahatékonyságot növelö hibrid rendszerek csökkentik az üzemeltetési költséget, így a beruházás megtérülési ideje rövidebb lehet a hagyományos meghajtáshoz képest.

A hibrid hajtásrendszerek emellett újdonságuk miatt nagy marketingértéket is képviselnek, amivel könnyebben lehet finanszírozási forrást találni, valamint a „hibrid” jelző a hajó piaci árát is növelheti. Ezek a „marketing hibrid” megoldások inkább a kedvtelési célú hajókra jellemzők, ahol a hajó újdonsága és különlegessége fontosabb szempont, mint az, hogy a hajóüzemben nincs vagy csak nagyon kevés olyan üzemállapot van, ahol a hibrid hajtás adta előnyök érvényesülhetnek.

\subsection{Csoportosítás a hibrid hajtás ener- gialánc felépítése szerint}

A hibrid hajtások energialánc felépítése szerinti csoportosítás a hajó mozgási energiájának az energiatárolókból történő előállítás módját vizsgálja. Három különböző elvet lehet megkülönböztetni:

\subsubsection{Soros hibrid hajtásrendszer}

A soros hibrid hajtásrendszer jellemzője, hogy a hajó meghajtásához szükséges mechanikai energiát egy erőgép (fögép vagy hajtómotor) biztosítja, amely a fedélzeten tárolt energiaformák közül csak az egyiket hasznosítja. Ettől eltérő fajtájú energiatárolókból történő üzemeltetéshez szükséges egy erőgép - munkagép gépcsoport (generátor gépcsoport), amely a hajtómotorhoz szükséges energiaformára alakítja át az energiatárolókban egyéb formában tárolt energiát. A generátor gépcsoport a hajókon legtöbb esetben fosszilis üzemanyagot (másodlagos energiatároló) hasznosít, s egy belső égésű motorral elöször mechanikus energiává, majd a generátorral (hidraulikus vagy elektromos) a hajtómotorhoz szükséges energiaformát állítja elő. A hajtómotor közvetlenül vagy az elsődleges energiatárolón keresztül táplálható a generátor egységről.

A gyakorlati megvalósításoknál a hajtómotor elektromos, pneumatikus vagy hidraulikus energiát használ. Az energiaelőállítás relatív rossz hatásfoka miatt a hidraulikus és pneumatikus rendszereket elsősorban úszó munkagépeken használják, ahol a fő gépüzem a hidraulikus vagy pneumatikus fedélzeti gépekkel történő munkavégzés, s a hajó hajtása csak másodlagos. Soros hibrid meghajtású hajóknál inkább a villamos energia az elsődleges energiaforma, mert előállítása és felhasználása relatív jó hatásfokkal történik, illetve jól szabályozható.

5. ábra: A soros hibrid hajtás energialánca

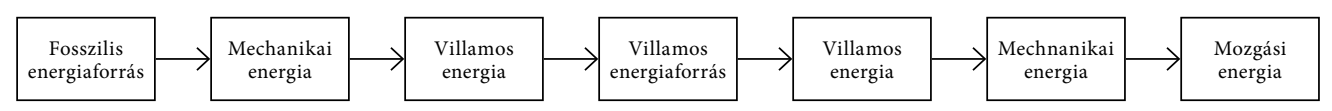


A soros hibrid rendszerek előnye, hogy a meghajtó motor közvetlenül hajtja a hajócsavart, így nincs szükség irányváltó vagy fordulatszám-változtató hajtómüre. További előny, hogy a fosszilis tüzelöanyagból elektromos energia előállítását több generátor-gépcsoportra lehet bontani, így a hajó részterheléses üzemeiben az energiatermelés egyenletesen szétosztható az egységek között úgy, hogy azok az optimális munkapont közelében üzemelhessenek. A géptéri elrendezés és a hajótest kialakítás tekintetében is kedvező a soros hibrid hajtás, mert a generátor gépcsoportok helye nem kötött. Mint minden elektromos energiatárolóval is rendelkező hibrid hajtásnál, a soros megoldásnál is fennáll az energiatárolók partról történő töltése, ami a fosszilis üzemanyagoknál olcsóbb lehet.

A soros hibrid meghajtás hátránya viszont, hogy a többszöri energiaátalakítás miatt a fosszilis energiahordozó felhasználása rosszabb hatásfokú, mint más kialakításoké.

A soros hibrid hajtást jellemzően az erősen változó teljesítménykihasználású hajókon alkalmazzák, úgy, hogy a villamosenergiatároló egyfajta tartalék tárolóként müködik a belső égésű motor terhelésének kiegyenlítésére, azaz a legjobb hatásfokú üzemben történő működtetésére.

\section{6. ábra: Példa egy soros hibrid hajtás felépítésére (forrás: www.elcomoryachts.com)}
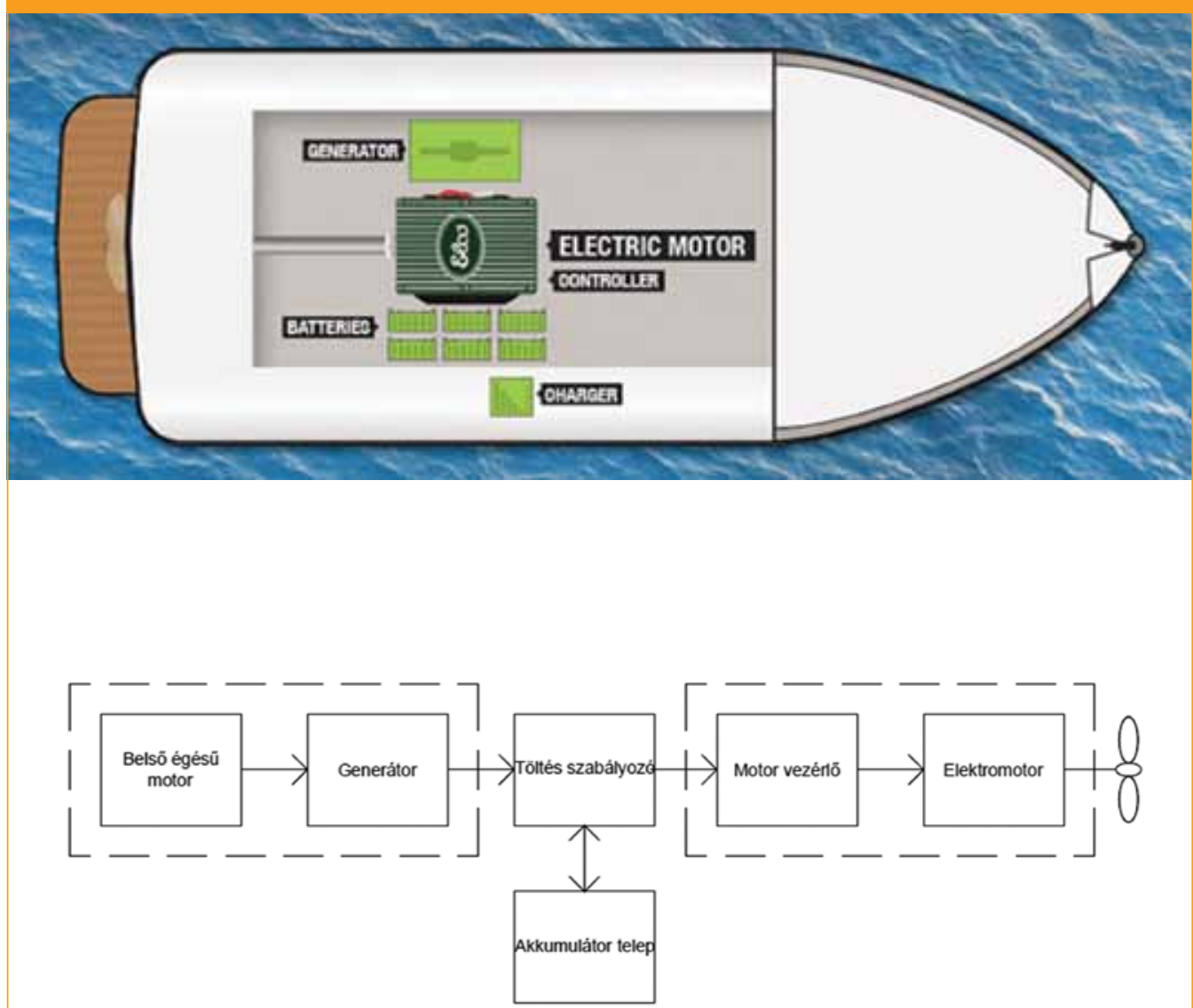


\section{Vízi közlekedés}

A 6. ábra egy soros hibrid hajtás elvi vázlatát mutatja, amely öt különbözö üzemállapotban müködhet:

- a belső égésü motorgenerátor egység nem üzemel, a hajót meghajtó elektromotort az akkumulátor telepről hajtják meg;

- a belső égésü motorgenerátor egység által szolgáltatott villamos teljesítmény egészét a meghajtó elektromotor veszi fel, az akkumulátorok nem töltődnek;

- a belső égésü motorgenerátor egység által szolgáltatott villamos energia egyik részét a meghajtó motor, másik részét az akkumulátorok töltése használja fel;

- a meghajtó elektromotor energiaigényét a belső égésü motorgenerátor egység és az akkumulátorok együttesen biztosítják;

- a hajó áll, így a meghajtó elektromotor nem igényel villamos energiát, $s$ a belső égésü motorgenerátor egység tölti az akkumulátorokat.

\subsubsection{Párhuzamos hibrid hajtásrendszer}

A párhuzamos hibrid hajtásrendszer jellemzője, hogy a hajó meghajtásához szükséges mechanikai energiát több, különböző energiaforrást használó erőgép biztosítja. Vagyis az egyes motorok egymástól függetlenül, vagy egymást segítve is müködtethetik a propulziós egységet, a fedélzeten tárolt energiaformák közvetlen hasznosításával. Alapvetően nincs elsődleges vagy másodlagos energiaforrás, a fontossági sorrendet a különféle hajóüzemek állítják fel. A meghajtó motorok egy összehajtó hajtóművön keresztül hajtják meg a közös propulziós egységet, esetleg az egyes motoroknak külön propulziós rendszere van. Ez utóbbi megoldás ritkán fordul elő a duplikált propulziós rendszerek bonyolultsága és költségessége miatt.
A párhuzamos hibrid hajtásoknál legtöbbször az egyik erőgép egy belső égésű motor, míg a másik egy elektromos motor. Ezek fosszilis tüzelőanyagot és villamos energiaforrást (akkumulátor, szuperkapacitás, üzemanyagcella, stb.) hasznosítanak, s állítanak elő mechanikai energiát, amivel az összehajtó hajtóművön keresztül meghajtják a propulziós egységet, általában hajócsavart.

A párhuzamos hibrid rendszerek előnye, hogy az energiahordozók felhasználása a lehető legkevesebb átalakítással, azaz veszteséggel történik, így a hajtás energiahatékonysága jobb, mint a soros hibrid hajtásoké (a fosszilis energia felhasználást tekintve). Az egyes meghajtó motorok jellemzően eltérő hajóüzemet szolgálnak ki, így a párhuzamos hajtásláncokat optimalizálni lehet az üzemeltetési profilból megállapított egyes hajóüzemállapotokra.

A párhuzamos hibrid meghajtás hátránya, hogy bonyolult mechanikai rendszereket (összehajtó hajtómü, üzemmód leválasztó tengelykapcsolók, üzemmód vezérlés, stb.) követel a mechanikai teljesítmények összehajtása, ami különösen nagy teljesítményszintek esetén problémás. A soros rendszerhez képest a párhuzamos hibrid hajtás megköti a tervező kezét a géptéri elrendezés és ezáltal a hajótest forma kialakításánál.

A párhuzamos hibrid hajtásrendszereket olyan hajókon szokták alkalmazni, ahol az üzemeltetés során több, eltérő teljesítmény szintü hajóüzem különböztethető meg pl. gyors haladás, lassú haladás, terhelt/terheletlen állapot, munkavégzés, pozícióban tartás, stb.

\section{7. ábra: A párhuzamos hibrid hajtás energialánca}

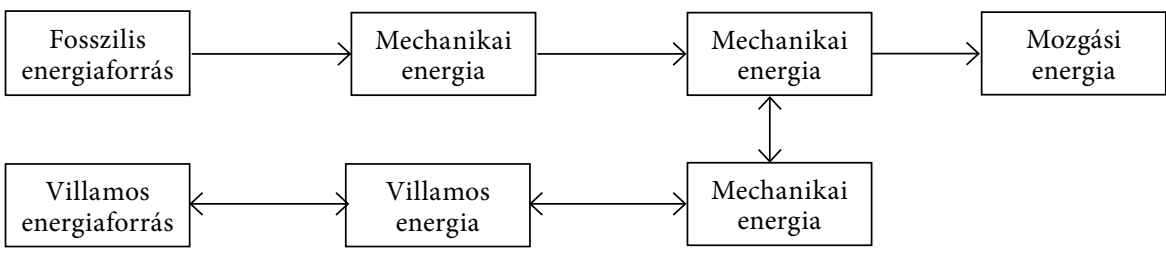



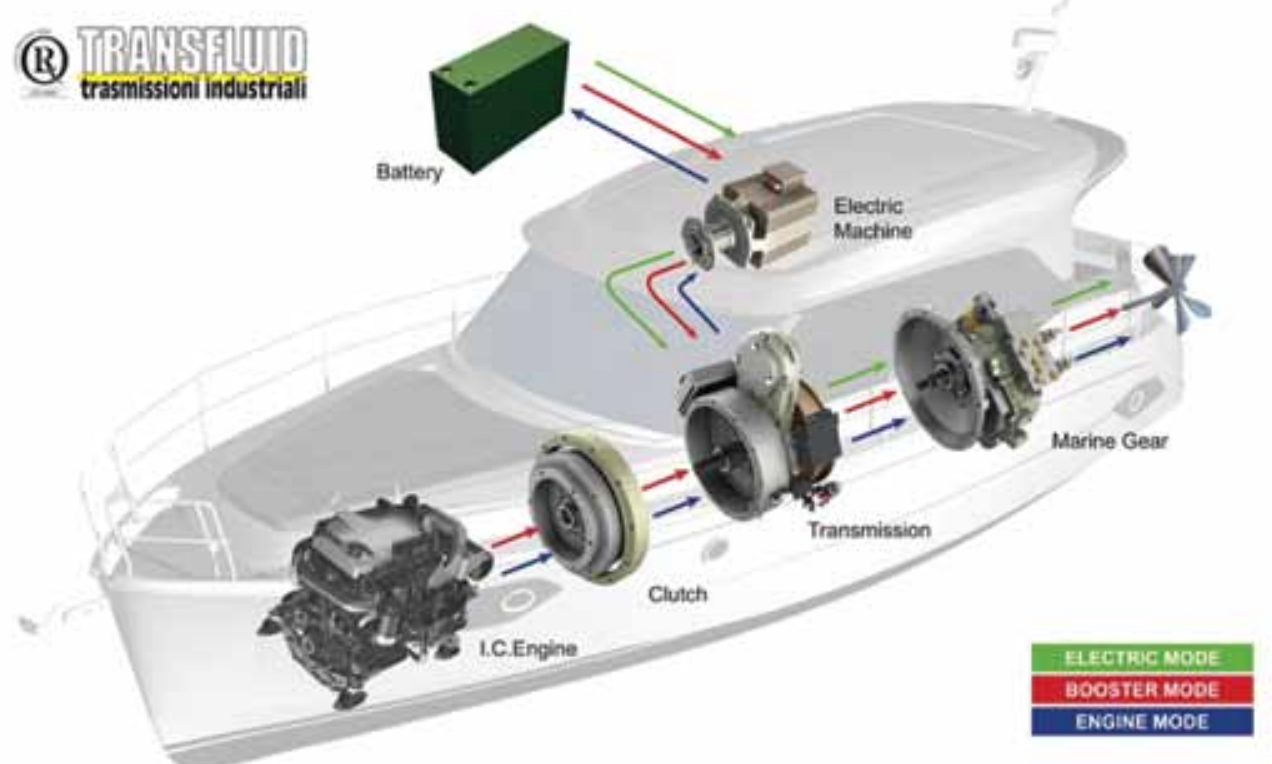

A 8. ábra egy párhuzamos hibrid hajtás vázlatát mutatja, amely három különböző üzemállapotban müködik:

- a belső égésü motor hajtja a propellertengelyt, míg az elektromotor terhelés nélkül szabadon vagy generátor üzemmódban forog;

- az elektromotor hajtja a propellertengelyt az akkumulátorokban tárolt energia felhasználásával. A belső égésű motor nem üzemel, és egy tengelykapcsolóval leválasztják a hajtásrendszerröl;

- a propellertengely hajtásához szükséges teljesítményt a belső égésü motor és az elektromos motor közösen biztosítja. Ezáltal mind a fosszilis, mind az akkumulátorokban tárolt energiát fogyasztják.

\subsubsection{Vegyes hibrid hajtásrendszer}

A vegyes hibrid hajtásrendszer a soros és a párhuzamos rendszer előnyeit próbálja egyesíteni és a hátrányos tulajdonságokat csökkenteni. Jellemzője, hogy a hajó meghajtásához szükséges mechanikai energiát (a párhuzamos hajtáshoz hasonlóan) különböző energiaforrásokból állítják elő, a fedélzeten tárolt energiaformák közvetlen hasznosításával. Azonban a hajtásnak lehet olyan üzemmódja, amikor az egyik energiaforrást egy másik meghajtó erőgép által igényelt energiaformára átalakítva hasznosítják (soros hajtás).

A vegyes hibrid hajtásoknál a propulziós egység meghajtó erőgépe - hasonlóan az előzőekhez - belső égésű motor és elektromos motor, azonban a fosszilis energiaforrás felhasználására belső égésű motor-generátor egység is rendelkezésre áll, amivel a villamosenergiatárolók tölthetők vagy az elektromos meghajtó motor üzemeltethető. A generátor egység belső égésű motorja lehet a propulziós egységet meghajtó „párhuzamos” meghajtó erőgép (tengelygenerátor) is, de lehet a hajóüzemi segédenergia előállítására használt generátor egység (segédgép) is. 


\section{Vízi közlekedés}

\section{9. ábra: A vegyes hibrid hajtás energialánca}

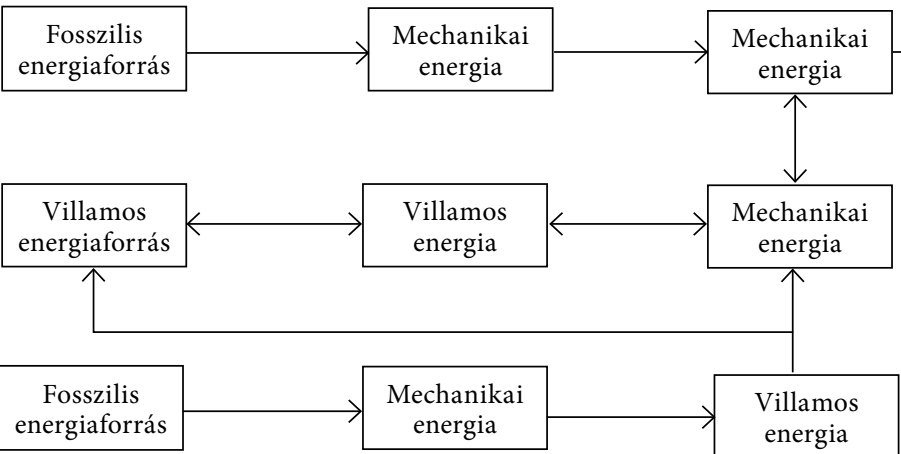

A vegyes hibrid rendszerek előnye a rugalmasság, vagyis az elkülönülő hajó üzemmódok külön-külön is, de az egyes üzemmódok változó teljesítménykihasználás kiegyenlítése is megvalósítható. Megfelelő hajtásrendszervezérléssel az optimális üzemállapotok (akár üzemanyag fogyasztás, akár az emisszió vagy más paraméter a fontos) beállíthatók.

A vegyes hibrid meghajtás hátránya, az összetettsége, a bonyolult mechanikai és vezérlési rendszerek költségessége. A hajtásrendszer minden egyes hajónál egyedi és gondos tervezést igényel, mind a belső tér, mind a hajótest kialakításánál.
A vegyes hibrid hajtásrendszereket olyan hajókon alkalmazzák, ahol az üzemeltetés során a változó teljesítménykihasználás és a több, eltérő teljesítményszintű hajóüzem is megjelenik.

A 10. ábra egy vegyes hibrid hajtás vázlatát mutatja, amely öt különböző üzemállapotban működik:

- a belső égésű motor hajtja a propellertengelyt, míg az elektromotor terhelés nélkül szabadon forog, vagy egy tengelykapcsolóval leválasztják a hajtásról;

- a propellertengely hajtásához szükséges teljesítményt a belső égésủ motor és az elekt-

\section{0. ábra: Példa egy vegyes hibrid hajtás felépítésére (forrás: WwW. elcomotoryachts.com)}

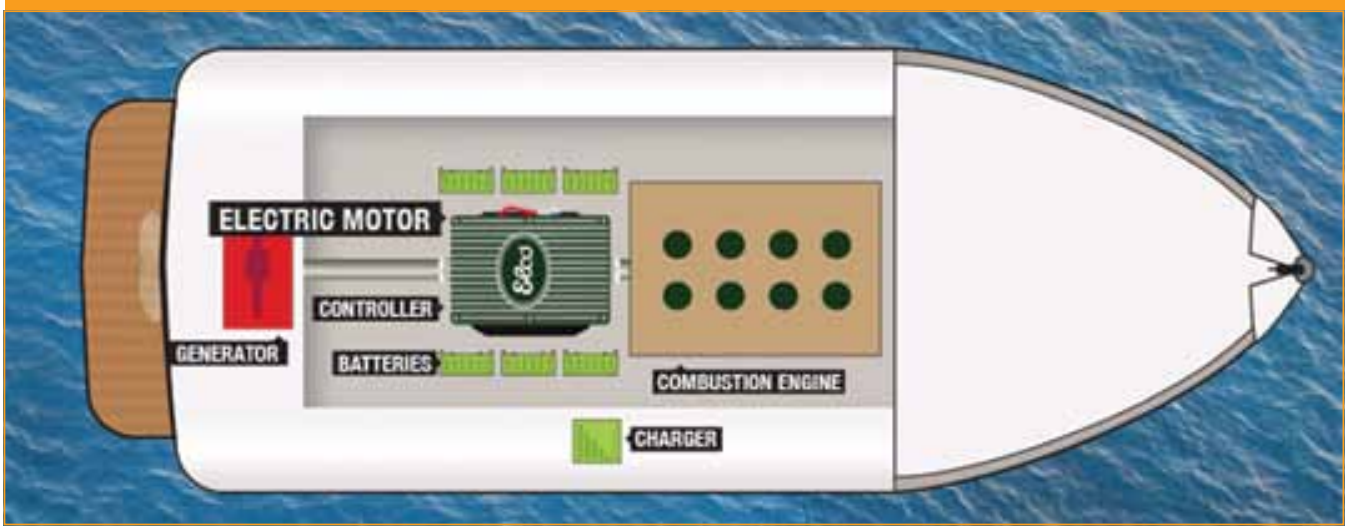


romos motor közösen biztosítja. Az elektromos motor energiaigényét a segédgép vagy az akkumulátorok biztosítják;

- a belső égésű motor nem üzemel, a hajót meghajtó elektromotor az akkumulátor telepről vagy a segédgépről hajtják meg;

- a belső égésű motor leválasztják a hajtásrendszerről, de a tengelygenerátor által szolgáltatott villamos teljesítményt a meghajtó elektromotorra és/vagy az akkumulátorok töltésére fordítják;

\section{1. ábra: "Menetdiagram" hegymenetre}

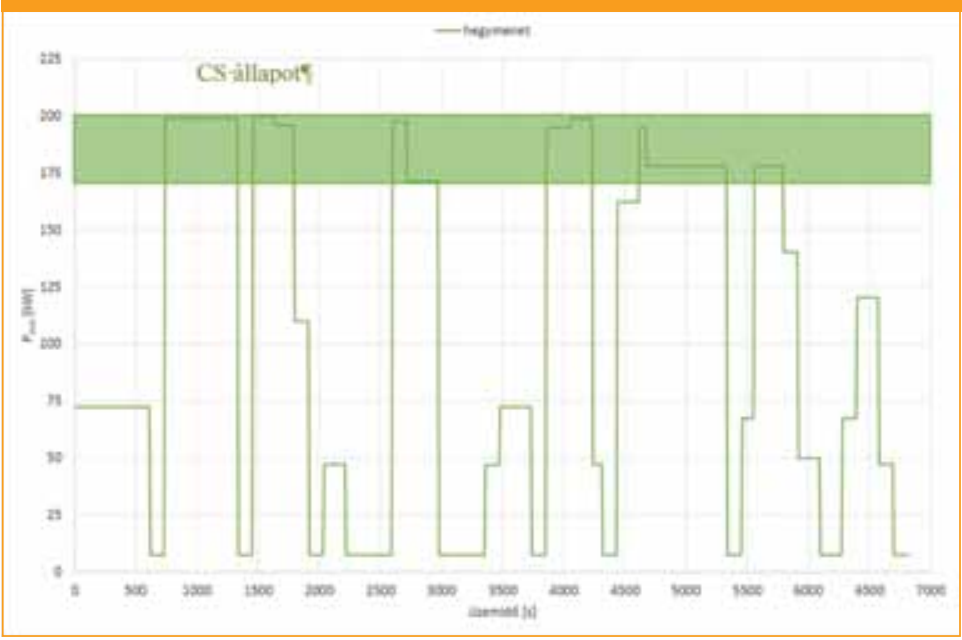

- a hajó áll, így a meghajtás nem igényel energiát, $\mathrm{s}$ a belső égésű motor a tengelygenerátorral vagy a segédgéppel tölti az akkumulátorokat és kiszolgálja a segédüzemet.

\section{A FIKTÍV HAJÓ JELLEGZETES ÜZEMÁLLAPOTAI}

Az üzemeltetési profil adatait felhasználva készíthetünk egy menetdiagramhoz hason-

ló, azonban az "y" tengelyen nem a sebességet, hanem a teljesítményigényt az üzemidő függvényében ábrázoló diagramot, amelyből a hajó és hajtásrendszerének üzemállapotai jobban láthatók. Hegy- és völgymenetre ezeket a diagramokat a 11.-12. ábrák mutatják.

Látható, hogy hegymenetben az üzemidő egy jelentős részében a hajó mozgása kb. 175$200 \mathrm{~kW}$ teljesítményt igényel. Ezen kívüli időben a teljesítményigény nem éri el a $\mathrm{kb}$. $75 \mathrm{~kW}$-ot. Völgymenetben rövid időtartamot le-

\section{2. ábra: "Menetdiagram" völgymenetre} számítva a szükséges teljesítmény szintén $\mathrm{kb} .85$

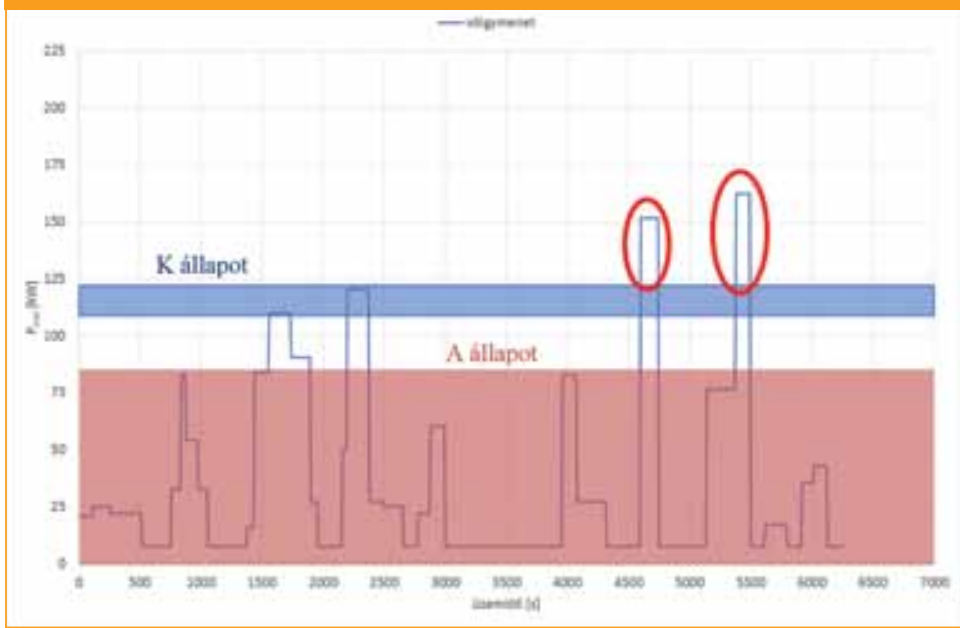
$\mathrm{kW}$ alatt marad, néhány 120 kW körüli „csúcs” látható csak. $\mathrm{Az}$ ábrán pirossal bekarikázott „csúcsok” a $120 \mathrm{~kW}$-nál számottevően nagyobb, 150-160 kW-os csúcsok, de a tényleges menetdiagramot (sebesség-idő összefüggés) megnézve kiderül, hogy a hajó itt csak tized csomókkal megy gyorsabban. A nagyobb teljesítményt a hajó ellenállásgörbéjének meredekebben emelkedő 
szakasza eredményezi. Célszerü tehát a sebességet kismértékben csökkenteni, így ezek a nagyobb teljesítményigények is $120 \mathrm{~kW}$ körüli értékre redukálhatók. Az adatokból az is számszerüsíthető, hogy hegymenetben az üzemidő több, mint 50\%-ban, völgymenetben kb. $85 \%$-ban, összesítve, teljes menetciklusra kb. 68\%-ban kisebb a teljesítményigény 85 kW-nál. A 175-200 kW-os teljesítményigény a teljes ciklusidő 18\%-ban, 120 kW körüli igény pedig mintegy 5\%-ban lép fel. Egyéb részteljesítményre marad kb. 9\%. Látható, hogy a fenti bontással három markánsan elkülönülö üzemállapotot lehet definiálni, ezek a következők:

- Alap (A) állapot (0-85 kW): völgymeneti normál sebességü haladás, hegymeneti kis sebességű haladás (manőverezés);

- Közepes (K) állapot (120 kW) körüli teljesítmény: völgymeneti csúcssebességen haladás;

- Csúcs (CS) állapot (175-200 kW): hegymeneti csúcssebességen haladás.

Völgymeneti haladáskor a $\mathrm{K}$ és A állapot felső határa közötti sebességkülönbség kevesebb mint $1 \mathrm{~km} / \mathrm{h}$, amely a teljes sebesség kb. 5\%-át jelenti. Elképzelhető, hogy a menetrend kismértékű módosításával biztosítható lenne egy olyan völgymeneti üzem, amelyben a teljesítményigény sehol sem haladja meg a $85 \mathrm{~kW}$-ot. Ez biztosan javítana az energiakihasználás hatékonyságán.

Az ilyen formában megadott menetdiagramok alatti terület gyakorlatilag az ahhoz az üzemhez szükséges összenergia mennyiségét adja. Hegymenetre ez 196 kWh-t, völgymenetre pedig - a korábban említett két csúcs $120 \mathrm{~kW}$-ra vételével - $59 \mathrm{kWh}$-t jelent.

\section{LEHETSÉGES HAJTÁSRENDSZER VÁLTOZATOK A FIKTÍV HAJÓNÁL}

A vizsgált mintahajó esetében kézenfekvő hajtásrendszer a hajócsavar hagyományos dízelmotorral, irányváltó hajtómüvön keresztül történő meghajtása. Azonban a korábbi fejezetekből (3. és 4. fejezetek) már körvonalazhatók az olyan hajtásrendszermegoldások, amelyek további vizsgálatra ér- demesek, elsősorban az energiahatékonyság szempontjából.

Az egyik ilyen megoldás az a párhuzamos hibrid rendszer lehet, amelyben az A állapotban egy $85 \mathrm{~kW}$-os elektromos motor adja a hajtási teljesítményt akkumulátortelepről táplálva, K állapotban egy megfelelő teljesítményü dízelmotort optimális munkapontjában járatva a teljesítmény egy része mechanikus hajtást biztosít a propellernek, miközben a hajtáshoz szükségtelen teljesítménnyel az összehajtóművön keresztül az "A" állapotban motorként, ilyenkor pedig generátorként üzemelö elektromos gépet hajtva tölti az akkumulátorokat. CS állapotban a dízelmotor és az elektromos motor együttesen biztosítja a hajtáshoz szükséges csúcsteljesítményt. A dízelmotor teljesítményét úgy kell meghatározni, hogy a hegymeneti üzemeltetése során, figyelembe véve a hegymeneti teljesítményigényt, elegendő teljesítményt szolgáltasson olyan mennyiségü/kapacitású akkumulátorok töltéséhez, amellyel az „A” és CS” üzemállapotok villamosenergia-igénye is kiszolgálható.

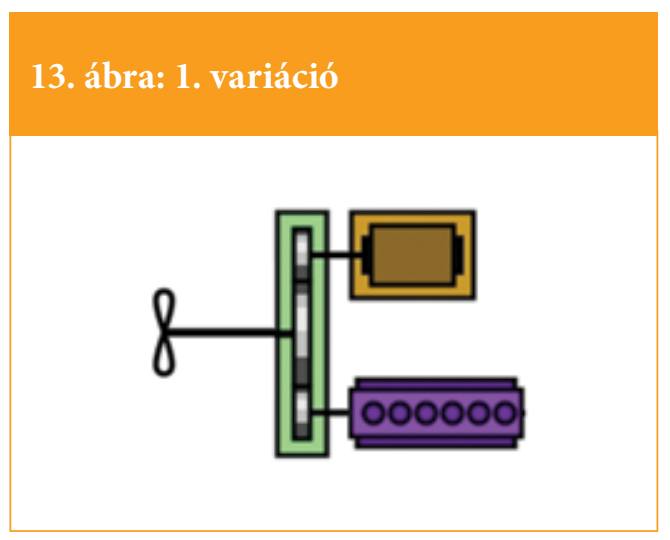

Másik lehetséges megoldás egy vegyes hibrid rendszer, amelynek elsősorban akkor lehet létjogosultsága, ha a jelenleg nem teljes mértékben kielégített segédüzemi energiaigényt egy külön dízelaggregátornak egyébként is biztosítania kell. Ebben a változatban a hajtáshoz használt dízelmotor az előző változattól eltérő teljesítményü lehet, hiszen a segédaggregátor megfelelő méretezésével az akkumulátorok is tölthetők. 


\section{4. ábra: 2. variáció}
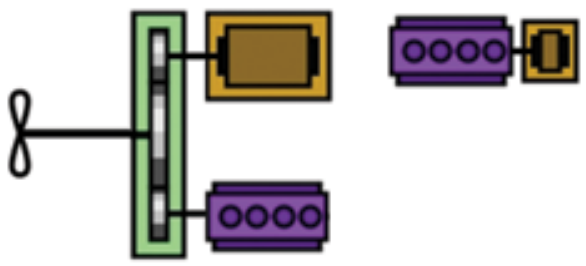

Ennek kapcsán felmerülhet a nem hibrid, hanem a klasszikus dízel-elektromos megoldás is, amelyben két megfelelően méretezett, különböző teljesítményű dízelaggregátor elektromos energiát termel mind a fó- mind pedig a segédüzem számára és a propeller hajtását egy elektromos motor biztosítja.

\section{5. ábra: 3. variáció}

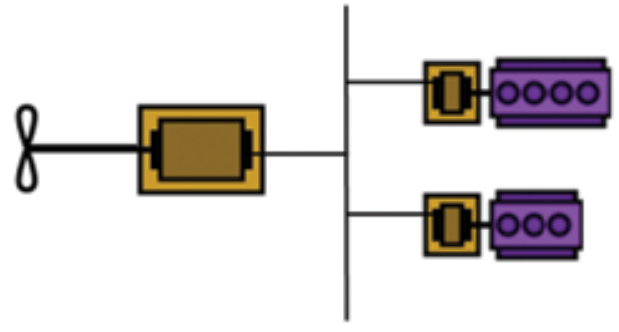

Az egyes variációk üzemeltetési költségekre gyakorolt hatását kell elsődlegesen vizsgálni, és amennyiben ezen a területen megtakarítás várható, akkor kell a nyilvánvalóan nagyobb beruházási költségek várható megtérülésének kérdésével foglalkozni.

A következőkben a hagyományos dízelmotoros meghajtás és a párhuzamos hibrid hajtás 1 . variációjának közelítő energetikai számítását mutatjuk be, különös tekintettel az üzemeltetési profil alapján egy menetciklusra számított várható üzemanyag-fogyasztásra.

\subsection{Hagyományos dízelmotoros hajtás- rendszer}

A mintahajónak tekintett BKV100 típusú hajó propulziós rendszere jelenleg a hagyományos dízelmotoros hajócsavar hajtás. Ez a dízelmotor erőforrásból, irányváltó hajtóműből, tengelyrendszerből és a hajócsavarból áll.

\section{6. ábra: Hagyományos hajtásrend- szer vázlat}

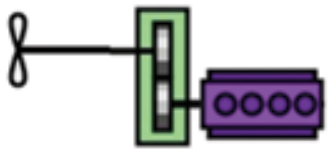

A hajtáslánc elemeiről és a hajótestről nem állnak rendelkezésre olyan részletes információk, amelyekkel pontosan kiszámíthatnánk a hajó egy menetciklusára eső üzemanyag-fogyasztását, ezért a szakirodalmi adatok alapján közelítő számítást végzünk. A hajtáslánc elemeinek paramétereit a következők szerint becsüljük.

- Főgép (dízelmotor)

A Doosan L126 TIH motor adatlapjáról [6] a motor teljes töltéséhez tartozó jelleggörbéje áll rendelkezésre (17. ábra), ami a fordulatszám függvényében mutatja a leadott tengelynyomatékot $\left(\mathrm{M}_{0}\right)$, illetve a fajlagos tüzelőanyag-fogyasztást $\left(\mathrm{BSFC}_{0}\right)$.

\section{7. ábra: Doosan L126 TIH jelleggörbéje}

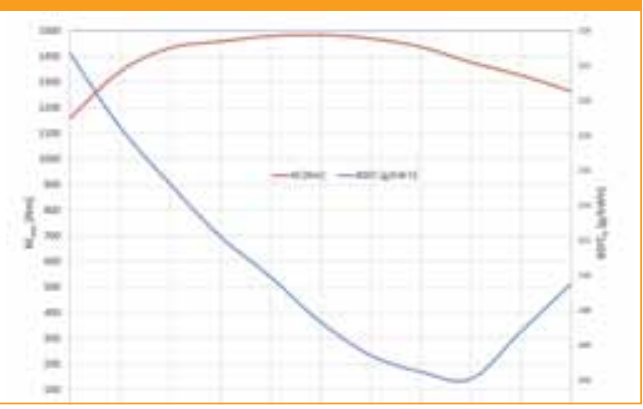




\section{Vízi közlekedés}

Az üzemeltetési profil részterheléses állapotaiban a motor fajlagos fogyasztását (BSFC) a fajlagos üzemanyag-fogyasztási térkép (vagy felület) alapján lehet meghatározni. Ez sajnos nem áll rendelkezésünkre ennél a motornál, ezért a számításhoz egy hasonló motor üzemanyag-fogyasztási térképét [7] torzítjuk a Doosan-motor ismert jelleggörbe adatai segítségével (18. ábra).

- Irányváltó hajtómü és tengelyrendszer Az energetikai számításhoz, a hajtómű fordulatszám módosítása $[4,5]$ alapján $\mathrm{i}=2,51$, illetve a propulziós rendszer mechanikai hatásfokát [8] alapján $\eta_{\text {mech }}=0,97$-re becsüljük.

- Hajócsavar

A BKV100 típusú hajókról rendelkezésre álló információk alapján a hajócsavart az alábbi táblázatban szereplő paraméterekkel jellemezhető Wageningen B típusú hajócsavarnak tekintjük.

- Hajótest

A hajótest tolóerő igényét az üzemeltetési profil meghatározásánál (1. fejezet) említett érdes hajótest felületre végzett ellenállás számítás eredményei szerint, [8] alapján becsült $\mathrm{t}=0,11$ értékű szívási tényezővel számítjuk. A hajótest - propeller együttműködését ezen kívül (szintén [8] alapján) w=0,36 sodor tényezővel, és $\eta \mathrm{F}=0,94$ forgási tényezővel jellemezzük.

A hagyományos dízelmotoros hajócsavar hajtásnál tehát a becsült hajtásrendszer adatokkal számítható a menetdiagram (3. fejezet) egyes sebességeihez a hajó effektív teljesítménye $\left(\mathrm{P}_{\text {eff }}\right)$, a hajócsavar és a motor fordulatszáma $\left(\mathrm{n}_{\text {mot }}\right)$, a teljes propulziós hatásfok $\left(\eta_{p}\right), s$ ebbôl a motor teljesítménye $\left(\mathrm{P}_{\mathrm{mot}}\right)$ és nyomatéka $\left(\mathrm{M}_{\text {mot }}\right)$. A becsült fajlagos üzemanyag-fogyasztás térképpel meghatározható a hajó fajlagos üzemanyag- fogyasztása is az egyes (holt vízi) menetsebességeknél (v).

\section{2. táblázat: BKV100 hajócsavar adatok}

\begin{tabular}{|l|c|c|}
\multicolumn{1}{|c|}{ Megnevezés } & Jelölés & Érték \\
\hline Hajócsavar átmérő & $\mathrm{D}[\mathrm{m}]$ & $0,9 \mathrm{~m}$ \\
\hline Emelkedés viszony & $\mathrm{P} / \mathrm{D}$ & 0,776 \\
\hline Nyújtott felületarány & $\mathrm{A}_{\mathrm{D}} / \mathrm{A}_{0}$ & 0,625 \\
\hline Propeller szárny szám & $\mathrm{z}$ & 4 \\
\hline
\end{tabular}

\section{8. ábra: Doosan L126TIH becsült fajlagos üzemanyag-fogyasztási térképe}

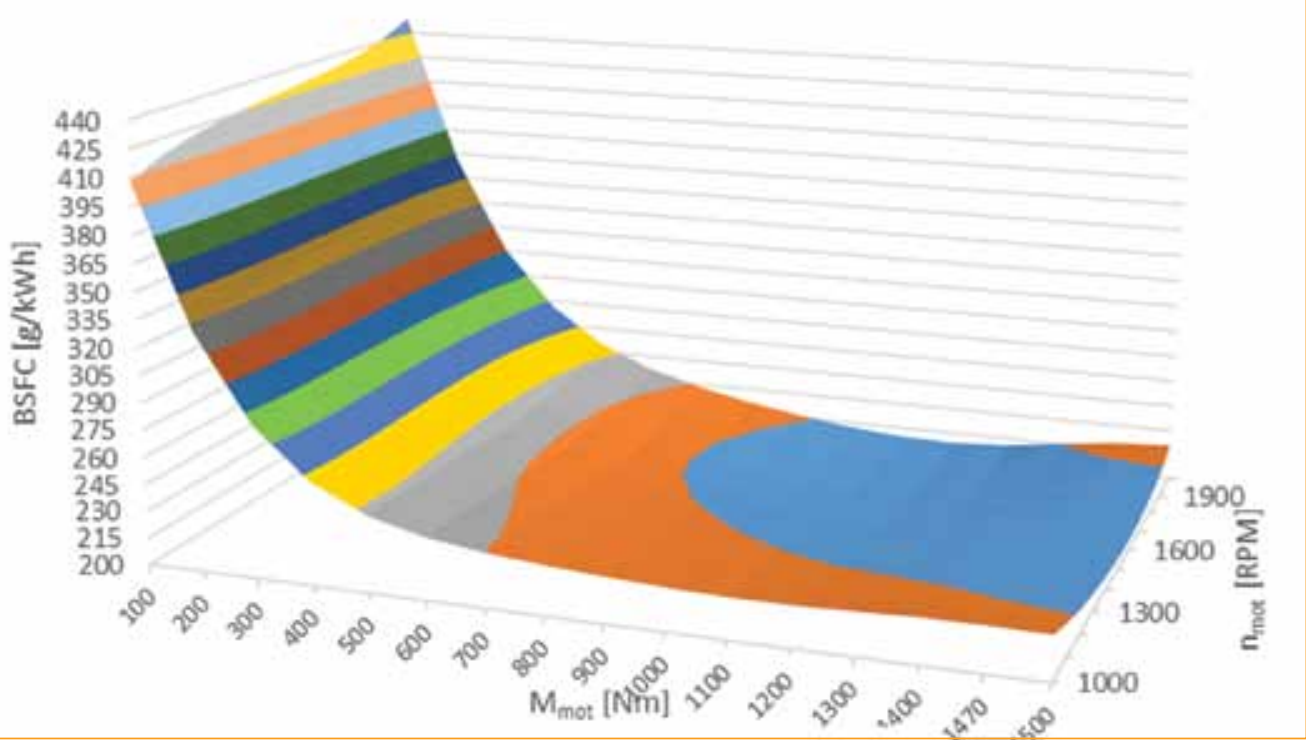




\section{Vízi közlekedés}

Az ábrából látható, hogy a hajó fajlagos üzemanyagfogyasztása (BSFC) alacsonyabb sebességeknél (azaz részterhelésen) jelentősen nő, akár másfélszerese is lehet a tervezési sebességéhez képest.

A hajó menetciklusa alapján, az egyes sebességekkel eltöltött időintervallumok $(\Delta t)$, fajlagos üzemanyag fogyasztás (BSFC) és motorteljesítmény (Pmot) szorzatait összegezve, a minta BKV 100 hajó becsült üzemanyag fogyasztása a teljes menetciklusban $62,65 \mathrm{~kg}$.

\subsection{Párhuzamos hibrid megoldás}

Ebben a változatban a legfontosabb kérdés a dízelmotor teljesítményének célszerű megválasztása. Első közelítésben a dízelmotor hegymenetben a teljes időtartam alatt $\mathrm{kb}$. névleges teljesítményen, völgymenetben pedig csak szükség ( $85 \mathrm{~kW}$ feletti teljesítményigény) esetén üzemelne. A dízelmotor-teljesítményt úgy kell megválasztani, hogy az ez alatti teljesítményszinthez hegymenetben szükséges energia mellett a völgymeneti teljes energiát és a hegymeneti, választott névleges teljesítményszint felett szükséges villamos energiát is megtermelje abban az időben, amikor a hegymeneti teljesítményigény kisebb a névleges motorteljesítménynél (az energiaátalakítás veszteségeit is figyelembe véve). A dízelmotor teljesítménye a maximális teljesítményigény és a villanymotor teljesítményének ( $85 \mathrm{~kW})$ különbségénél kisebb nem lehet annak érdekében, hogy a hegymeneti csúcsteljesítmény-igény is kielégíthető legyen.

Ez a vizsgált esetben min. $115 \mathrm{~kW}$-ot jelent. A teljesítmény meghatározásához a korábban mutatott hajtási energiaszükséglet használható. A „menetdiagramok” felhasználásával kiszámítottuk, hogy mekkora az adott menetszakaszon a mechanikai és villamos energiaigény, illetve, hogy egy választott dízelmotor-teljesítmény esetén a járó dízelmotor mekkora elektromos energiává alakítható mechanikai többletenergiát termel. A teljes ciklusra vonatkozó elektromos energiaigény és veszteségekkel növelt elöállítható elektromos energia összevetése után meghatározható az a teljesítményű dízelmotor, amellyel a feladat megoldható. Az energiaátalakítás, akkumulátor töltés és merítés veszteségét első közelítésben összesen $85 \%$-ra vettük. Az így kapott teljesítménnyel és a motor fajlagos fogyasztásával a ciklusra eső teljes fogyasztás már számítható. A vizsgált teljesítménytartományban a gyártók által közölt adatok szerint a motorok fajlagos fogyasztása gyakorlatilag azonos, ezért a számításokhoz egy, a BKV hajókban jelenleg is használt Doosan- motor fogyasztását vettük alapul. A számítás eredményei a 3. táblázatban láthatók.

\section{3. táblázat: A célszerủ motorteljesítmény számítása}

\begin{tabular}{|c|c|c|c|c|c|c|c|c|c|c|}
\hline & \multicolumn{10}{|c|}{ választott motorteljesítmény $[\mathrm{kW}]$} \\
\hline & 115 & 120 & 130 & 140 & 150 & 160 & 170 & 180 & 190 & 200 \\
\hline Rendelkezésre álló elektromos energia [kWh] & 68.0 & 73.3 & 84.3 & 95.2 & 106.5 & 117.8 & 129.4 & 142.0 & 156.4 & 171.6 \\
\hline Összes elektromos energiaigény [ $\mathrm{kWh}$ ] & 89.7 & 85.3 & 77.1 & 68.9 & 61.0 & 53.1 & 45.6 & 39.3 & 35.2 & 31.9 \\
\hline Ciklus fogyasztása [kg] & 49.6 & 51.7 & 56.1 & 60.4 & 64.7 & 69.0 & 73.3 & 77.6 & 81.9 & 86.2 \\
\hline
\end{tabular}


A számokból és a 20. ábrán levő diagramból kiderül, hogy a vizsgált esetben már egy $130 \mathrm{~kW}$-os dízelmotor hegymeneti folyamatos és völgymeneti rövid idejü (amikor a szükséges teljesítmény a $85 \mathrm{~kW}$-os villanymotorral nem fedezhető) névleges teljesítményen való járatása mellett biztosítható mind a völgymeneti, mind pedig a hegymeneti nagyobb sebességekhez szükséges elektromos energia.

A bemutatott párhuzamos hibrid hajtás (130 kW dízelmotor $+85 \mathrm{~kW}$ villamos motor) egy menetciklusra vonatkozó becsült üzemanyag-fogyasztását összehasonlítva a hagyományos dízelhajtáséval megállapítható, hogy a hajó a hibrid hajtással kb. 10,5\% üzemanyagmegtakarítás érhető el. Persze a mintahajó üzemanyag-fogyasztás számítása nagyon sok közelítéssel és becsült adattal történt, ezért ez a számszerü eredmény nem tekinthetö mérvadónak. Azt azonban jól mutatja, hogy lehetséges gazdaságosabb üzemeltetést elérni a hibridhajtás-rendszerekkel a változó teljesítmény kihasználású hajóknál, jóllehet a szárazföldi járművekkel ellentétben a féküzemi energiavisszatáplálás hajóknál nem lehetséges. Továbbá az üzemanyag-fogyasztás különbség és a számítás menete rámutatott arra is, hogy a hibrid hajtás létjogosultságát csak pontos üzemeltetési profil és hajtásrendszer adatok (üzemanyag-fogyasztási térkép, hajótest ellenállás, gépek hatásfok diagramjai, stb.) ismeretében lehet energetikai számítással megítélni.

\section{GAZDASÁGOSSÁGI KITEKINTÉS ÉS KONKLÚZIÓ}

Az elsősorban az üzemanyagköltségektől függő müködési költségek mellett a hajtásrendszer tervezése során a beruházási költségeket is figyelembe kell venni. E cikkben a hangsúly az energiafelhasználás hatékonyságán és a hibrid rendszer műszaki szempontú alkalmazhatóságának megvizsgálásán van, de azért egy durva, szakirodalmi adatokon alapuló beruházási költség összevetést mindenképpen szükséges az elemzés végén bemutatni.

A költségszámítás a [9] alapján készült. Ebben alapvetően egységnyi teljesítményre vetített fajlagos beruházási költségek találhatók. Több esetben, pl. a motoroknál, a költséget nem csak a teljesítmény, hanem egyéb jellemzők (mint pl. tömeg, furatátmérő, stb.) is befolyásolják, amelyek az említett irodalomban már nem kerülnek részletezésre. A fiktív hajóra egy ilyen összevetés elfogadható, de egy tényleges hajó esetén pontosabb költségszámításra van szükség. A vizsgált esethez tartozó bemenő paraméterek alapján elkészített számítás eredményeit a 4 . táblázat tartalmazza.

A táblázatból látható, hogy a hibrid megoldás elsőre nem tünik sokkal drágábbnak. Fontos azonban tisztázni, hogy a fenti költségek pontosan mit tartalmaznak, mert egy ilyen, ebben a hajókategóriában Magyarországon mindenképpen újnak számító rendszer beépítése és beüzemelése is komoly költségösszetevő lehet. Ilyen feladatra csak egy erre szakosodott, tapasztalatokkal rendelkező cég alkalmas, míg egy mechanikus rendszer átalakítása (motorcsere és ezzel kapcsolatos módosítások) lényegesen egyszerübb feladat.

Mindezek mellett célszerü szem előtt tartani más, talán nehezebben számszerüsíthető, mégis jelent- 
4. táblázat: Beruházási költségek alakulása

\begin{tabular}{|l|c|c|}
\hline \multicolumn{1}{|c|}{ Szükséges elemek } & eredeti verzió & $\begin{array}{c}\text { 1. variáció - } \\
\text { hibrid }\end{array}$ \\
\hline $\begin{array}{l}4 \text { ütemü dízelmotor, } \\
200 \mathrm{~kW}\end{array}$ & 72000 & \\
\hline $\begin{array}{l}4 \text { ütemü dízelmotógek [EUR] } \\
130 \mathrm{~kW}\end{array}$ & & 52000 \\
\hline normál hajtómű & 6000 & \\
\hline hajtómű (PTI/PTO-val) & & 7418 \\
\hline $\begin{array}{l}\text { elektromos motor } \\
\text { (indukciós, 85 kW) }\end{array}$ & & 4250 \\
\hline $\begin{array}{l}\text { frekvenciaváltó (active- } \\
\text { front-end) }\end{array}$ & & 17550 \\
\hline $\begin{array}{l}\text { akkumulátorok (töltés- } \\
\text { vezérlővel) }\end{array}$ & & 9914 \\
\hline \multicolumn{1}{|c|}{ összesen } & $\mathbf{7 8 0 0 0}$ & $\mathbf{9 1 1 3 2}$ \\
\hline
\end{tabular}

kező előnyt és hátrányt. Egy hibrid rendszer alkalmazása közforgalmú hajón előremutató, társadalmi megítélése mindenképpen pozitív lehet, a cég helyes marketinggel több felhasználót tud esetleg a hajóra vonzani, ami bevételnövekedést jelenthet. A realizálható üzemanyag-fogyasztás csökkenése egyértelmüen a károsanyag-kibocsátás csökkenését is jelenti, ami szintén kedvező társadalmi hatással bír. A völgymeneti tiszta villamos üzem halk és megfelelő vezérlés esetén arra is van lehetőség, hogy a kikötések során is csak az elektromos motorok üzemeljenek, ami a ki- és beszálló utasok számára jár kisebb zajhatással és így nagyobb vonzerővel. Ugyanakkor azt is el kell mondani, hogy azon cégeknek, akik eddig nem foglalkoztak ilyen rendszerrel, több és új berendezéssel, valamint más jellegü üzemeltetéssel kell megismerkedni, más szakértelmü emberekre is szükség van a korábbiak mellett, más karbantartási stratégiát kell kidolgozni a hajókra. Mindezek általában többletköltséget jelentenek.

Fentiekből látható, hogy a hibrid rendszerek hagyományos mechanikus rendszerekkel való gazdasági vonatkozású összevetése is komplex feladat.

A tengeri hajózásban a propulziós rendszereket gyártó cégek ma már külön szolgáltatás- ként az optimális propulziós rendszer kiválasztásához és méretezéséhez hajóenergetikai rendszer számításokkal segítik a döntéshozókat. A jelen cikkben bemutatott vizsgálat - bár nem valós, hanem csak ahhoz közeli, kitalált példán alapul - jól szemlélteti, hogy a belvízi hajózásban is alkalmazhatók ezek a számítások. Ugyanis a példaként bemutatott budapesti közforgalmú hajóközlekedésben, a jelenlegi menetrend mellett is lehet létjogosultsága a hibrid hajtásnak müszaki és gazdasági szempontból. A fiktív hajón végzett elemzésekből kitűnik, hogy mind az üzemeltetési profil jellege, mind pedig az ez alapján elvégzett üzemanyag-fogyasztásra vonatkozó eredmények ígéretesek. A tárgyalt számítási módszertan alkalmazható a konkrét gyakorlati feladatok során, vagy a többi, itt nem tárgyalt variáció elemzéséhez is. A bemenő adatok pontosságától függően alkalmas a várható - alapvetően müszaki vonatkozású előnyök kielégítő pontosságú számszerűsítésére. Ezt kiegészítve egy ajánlatokon alapuló beruházási költségszámítással, valamint a további (akár teljes életciklusra vonatkozó) üzemeltetési költségek kalkulálásával, egy olyan rendszerhez jutunk, mely megfelelő alapot biztosít az ilyen komplex rendszerek előzetes vizsgálatához és nagy összegü beruházások döntés-elökészítéséhez.

A BKV az 1980-as években épített hajóit folyamatosan karbantartotta, és a lehetőségek szerint korszerűsítette. Egy kiválasztott hajóval el lehetne végezni a kísérleteket, és ez alapján meghatározhatóvá válik a fejlesztés iránya. A vizsgálat alapján új hajótípust lehet kifejleszteni, legyártani az eredmény többcélú felhasználásával (menetrend szerinti hajózás, vonalhajózás, sétahajózás).

A közlekedés, ezen belül a teherszállítás, a turizmus és az agglomerációval való közvetlen kapcsolatnak a Dunára koncentrálása Budapest számára tisztább levegöt, egyedi karaktert, tehermentes rakpartokat és jelentős idegenforgalmi bevételeket kínál, valamint egy fenntartható fővárost, amely Európa elé követendő példát állít, és harmonikusan illeszkedik az Európai Unió hosszú távú környezetvédelmi stratégiájába is. 


\section{FELHASZNÁLT IRODALOM}

[1]

[2]

[3]
Bicsák György, Hornyák Anita, Veress Árpád: Numerical Simulation of Combustion Processes in a Gas Turbine, ICNPAA 2012 World Congress: 9th International Conference on Mathematical Problems in Engineering, Aerospace and Sciences, July 10, 2012 - July 14, 2012, American Institute of Physics, Conference Proceedings, Vol. 1493, old. 140-148; DOI:http://dx.doi.org/10.1063/1.4765482,2012 Kiss Csaba: Villamos hajtású nagyvasúti vontatójárművek fejlődési irányai, Vasútgépészet, 2015 III.szám, 2015 Hargitai L. Csaba, Dr. Simongáti Győző: Hajógépek, Egyetemi tananyag, Budapesti Müszaki és Gazdaságtudományi Egyetem, Közlekedésmérnöki és Jármümérnöki Kar, 2012 ISBN 978-963-279619-2, Typotex Kiadó

\section{The possibilities of} applying hybrid powered ships in the river public transport

Most of the world's vessel fleets consist of ships that perform intercontinental transportation, so their engines operate almost in the entire span of their operating life in the proximity of their design operating state. Near-static operating conditions can be well planned or optimized for the most feasible optimum energy efficiency. However, in inland waterway shipping, there is a wide range of energy use in the engine operation, resulting from variable current speeds, frequent maneuvers and special operating requirements. In the case of the generally used inland waterway vessels the utilization of built-in power is stochastic, i.e. changes depending on the actual route and the cargo, so it is up to the experience of the planning and operating personnel to set the optimum (best efficiency) power point of the machine operation as a design target. In contrast, in passenger ships serving river public transport, the utilization of the engine's power can be planned with a good approximation, as the vessels move on a nearly identical track, and practically under the same conditions. Using the computational results, the authors of this paper discuss the possibility of hybrid powered ships carrying public river traffic in Budapest. https://www.bkv.hu/hu/hu/ jarmuveink/hajo/a _ hajok_ bemutatasa (2017.02.28)

www. hajoregiszter.hu, (2017.02.28)

Doosan L126TI Marine Engine Data Sheet, Doosan Infracore, Seoul, Korea, 2005

Ximing Wang, Hongwen $\mathrm{He}$, Fengchun Sun, Jieli Zhang: Application Study on the Dynamic Programming Algorithm for Energy Management of Plugin Hybrid Electric Vehicles, Energies 2015, 8(4), old.:3225-3244; DOI:http://dx.doi.org/10.3390/en8043225 Hajók Kézikönyv, Műszaki Könyvkiadó, Budapest, 1981

Bas Kwasieckyj: Hybrid propulsion systems Efficiency analysis and design methodology of hybrid propulsion systems, Master thesis, TU Delft, 2013

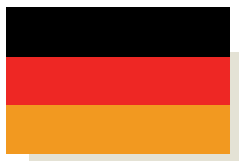

\section{Die Möglichkeiten der Anwendung von Schiffen mit} Hybridantrieb in dem öffentlichen Verkehr

Die meisten Schiffsflotten der Welt bestehen aus Schiffen, die interkontinentalen Transport durchführen, so dass ihre Motoren in der fast gesamten Betriebszeit in der Nähe ihres geplanten Betriebszustandes arbeiten. Der nahezu statische Betriebszustand kann gut geplant und für eine möglichst optimale Energieeffizienz optimiert werden. Die Binnenschifffahrt kann jedoch mit einem breiten Energieverbrauchsbereich gekennzeichnet werden, der sich aus den variablen Stromgeschwindigkeiten, häufigen Manövern und speziellen Betriebsanforderungen ergibt. Bei den allgemein eingesetzten Binnenschiffen ist die Ausnutzung der eingebauten Leistung der Ma-schine stochastisch, in der Abhängigkeit der tatsächlichen Strecke und Fracht, so dass es von den Erfahrungen des Konstrukteurs und des Betreibers abhängt, den optimalen Betriebspunkt (mit der besten Effizienz) als Planungsziel zu setzen. Im Gegensatz dazu kann bei Fahrgastschiffen, die in dem öffentlichen Flussverkehr eingesetzt sind, die Ausnutzung der Motorleistung mit einer guten Näherung geplant werden, da sich diese Schiffe auf einer nahezu identischen Strecke und praktisch unter den gleichen Bedingungen bewegen. Mit Hilfe von rechnerischen Ergebnis-sen diskutieren die Autoren dieser Arbeit die Möglichkeiten der Anwendung von Schiffen mit Hybridantrieb in dem öffentlichen Flussverkehr in Budapest. 